\title{
Microleakage of Glass lonomer Cement Restorations
}

\author{
Lado Davidović1, Slavoljub Tomić1, Mihael Stanojević1, Slavoljub Živković ${ }^{2}$ \\ 'Department for Restorative Dentistry and Endodontics, School of Medicine Foča, University in East Sarajevo, \\ Foča, Bosnia and Herzegovina; \\ ${ }^{2}$ Clinic for Restorative Dentistry and Endodontics, School of Dentistry, University of Belgrade, Belgrade, Serbia
}

\begin{abstract}
SUMMARY
Introduction A lack of appropriate adhesiveness is one of the biggest problems in the restorative dentistry today and the main cause of the microleakage between restorations and hard dental tissue. The aim of this study was to assess the adhesiveness of two different glass ionomer cement restorations class $V$ on the hard dental tissue using the SEM analysis and dye penetration test.

Material and methods The study included 80 extracted teeth for orthodontic reasons (premolars and molars) in both genders and different age. On the vestibular and oral side of the teeth, adhesive preparations class $V$ were done (size $3 \times 2 \times 2 \mathrm{~mm}$ ). On the vestibular preparation, GC Fuji II was applicated and GC Fuji II LC-improved on the oral side. The quality of the adhesiveness between restorations and hard dental tissue was evaluated using the SEM analysis and dye penetration test ( $0.5 \%$ basic fuxsin). Linear penetration of the dye was observed using 10 times magnification. Results The results showed that microleakage was presented with both materials but a ratio was less with Fuji II LC compared with Fuji II. Also, the microleakage was less on the occlusal parts of the restorations than on the gingival, with both materials. Microleakage was noticed in $93.44 \%$ teeth with Fuji II GJC restorations with index of microleakage of 148 on all edges. Fuji II LC GJC restorations showed microleakage in $68.4 \%$ teeth with index of microleakage 75 on all edges. The SEM analysis showed that both glass ionomer materials had better adhesiveness to the enamel than to the dentin. The average gap length between Fuji II LC and dentin was $9 \mu \mathrm{m}$ and Fuji II $17 \mu \mathrm{m}$, respectively.

Conclusion Better adhesiveness to the hard dental tissue was achieved with materials of the newer generations, resin modificated glass ionomer cements.
\end{abstract}

Keywords: microleakage; adhesiveness; glass ionomer cement

\section{INTRODUCTION}

Although we are at the beginning of the third millennium, it is still clear that there is no such material invented to be adequate replacement for the hard dental tissue, considering its physical, chemical and biological characteristics. Nowadays, in restorative dentistry, the glass ionomer cements and composite materials are in common use for restorative procedures. Nevertheless, the biggest problem in the application of composite materials in the contemporary restorative dentistry is the appearance of microcracks between the material and hard dental tissue. It is the result of numerous influences, but the most significant is the design of the cavity preparation, manner and technique of restoration, dimensional changes in the material during hardening, differences in the thermal expansion coefficient between teeth and restorative material or, more exactly, because of differences between the thermal conductivity of the teeth and filling. Clinical manifestations are discoloration on the edges, damages of the filling and irritation or inflammation of the dental pulp accompanied by secondary caries $[1,2]$.

In restorative dentistry, GICs are also used as a material in numerous indications. They are able to create chemical type of connection with hard dental tissue. Those materials have gone through great changes since their first appearance in the 1970's (conventional GICs). The crucial change was adding of the composite resins to conventional GICs and the creation of the resin-modified GJCs. The main purpose of resin is the improvement of mechanical and aesthetical features of GJC and the protection of the important acid-base reaction during the hardening of material [3,4]. The feature that makes this materials so unique is almost an identical coefficient of thermal expansion as of hard dental tissue, significant adhesion, biocompatibility and fluoride releasing [5-8]. Because of the above mentioned characteristics, GIC is the material in expansion and it is frequently used in numerous indications in everyday clinical practice [9].

The aim of this study was to assess the adhesiveness of two different glass ionomer cement restorations class $\mathrm{V}$ on the hard dental tissue using the SEM analysis and dye penetration test.

\section{MATERIAL AND METHODS}

The study included 80 extracted teeth for orthodontic reasons (premolars and molars). They were extracted for the orthodontic reasons and kept in saline until the beginning of the experiment. For 60 teeth, microleakage was evaluated using the dye penetration test and for 
20 teeth the quality of adhesivness was assessed by the SEM analysis.

\section{Qualitative examination of adhesiveness using dye penetration test}

On the vestibular and oral side of all teeth, the singlesided preparations were made (adhesive type, class V), with rounded cavity walls (dimensions $3 \times 2 \times 2 \mathrm{~mm}$ ). The edges of cavities were completely in enamel, without beveling the cavity walls. The high speed diamond drill with water cooling was used for preparation in enamel. For preparation in dentin, the handpiece with rounded steel burs was used. After cavity preparation, the conditioning of the surface was performed using Cavity Conditioner, than cavities were washed with water and dried by sterile cotton pads (without overdrying). In the prepared cavities, the material was applied, according to the manufactur's instructions.

On the vestibular side, the classic GC Fuji II and on the oral side resin-modified GC Fuji II LC improved were applied. After spreading the material, the matrix was applied over, and for GC Fuji II LC improved, the polymerization of material was done using Bluephase C8 (Ivoclar Vivadent) halogen lamp. After matrix removal, the fillings were coated with GC Fuji Varnish, dried and then polished. Afterwards, the teeth were covered with double layer of varnish (not only the fillings, but the area of $1 \mathrm{~mm}$ around them) and submerged in solution of $0.5 \%$ basic fuschin during next 72 hours. After that, the teeth were cut in vestibulo-oral direction, following the sagittal level. Dye penetration was observed under the 10 times magnifying glass, both on the occlusal and gingival edges. The depth of penetration vas evaluated according to the following criteria (schematics is on Figures 1a and 1b) [9].

\section{SEM analysis of the adhesiveness between tooth restoration and hard dental tissues}

After cutting the teeth in vestibulo-oral direction, following the sagittal level, cross sections were fixed on metal rollers and coated with the thin layer of gold. The SEM analysis was preformed using the SEM JEOL JSM-5300 microscope, with max voltage $30 \mathrm{kV}$ and with different magnification. Samples were photographed by the JVC GC-X3E camera and ILFORD FP4 PLUS 125 negative film (125 ASA, 22 DIN, EI 125/22).

Photomicrographies were used for analysis of the junction between GIC and hard dental tissue and also for analysis of microcracks between GIC and hard dental tissue. The software SemAfore 4 was used for analysis of photomicrographies and to measure the marginal gap between restaurative material and hard dental tissue. After all the data were collected and processed, the following statistical tests were used: Wilcoxon signed-rank test, MannWhitney test, ANOVA and Kruskal-Wallace test.
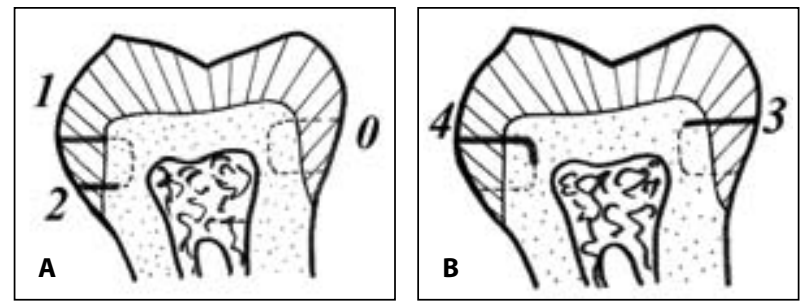

Figure 1. Shematic view of evaluating the microleakage Slika 1. Shematski prikaz vrednovanja stepena mikrocurenja

0 - microleakage not observed; 1 - microleakage up to enamel-dentine junction; 2 - microleakage above to enamel-dentine junction; 3 - microleakage up to the bottom of the axial wall; 4 - microleakage in the bottom of the cavity

0 - nema mikrocurenja; 1 - mikrocurenje do gleđno-dentalne granice; 2 - mikrocurenje preko gleđno-dentalne granice; 3 - mikrocurenje do dna aksijalnog zida; 4 - mikrocurenje zahvata i dno kaviteta

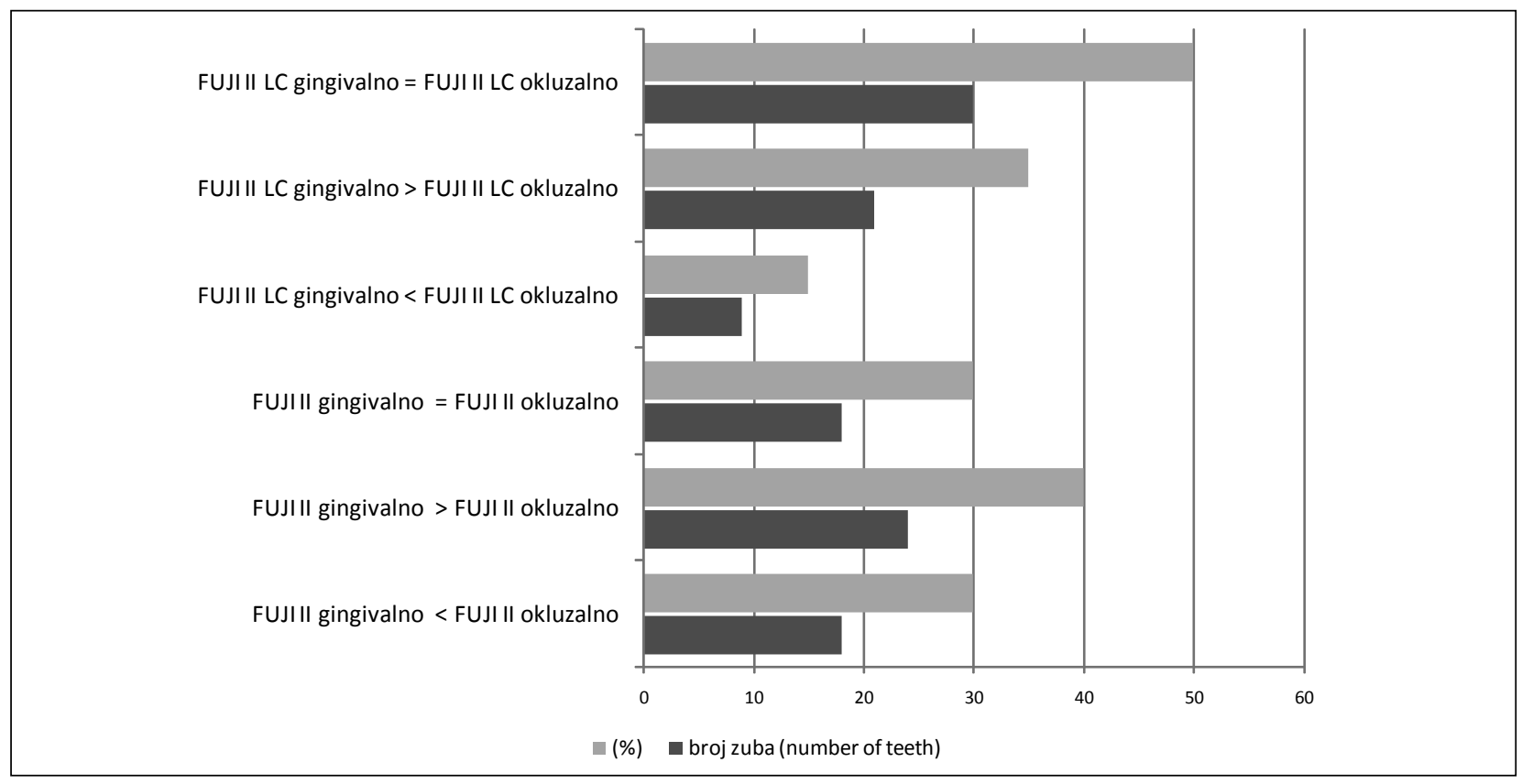

Graph 1. Microleakage on the gingival and occlusal wall for Fuji II and Fuji II LC

Grafikon 1. Stepen mikrocurenja na gingivalnom i okluzalnom zidu kod Fuji II i Fuji II LC 


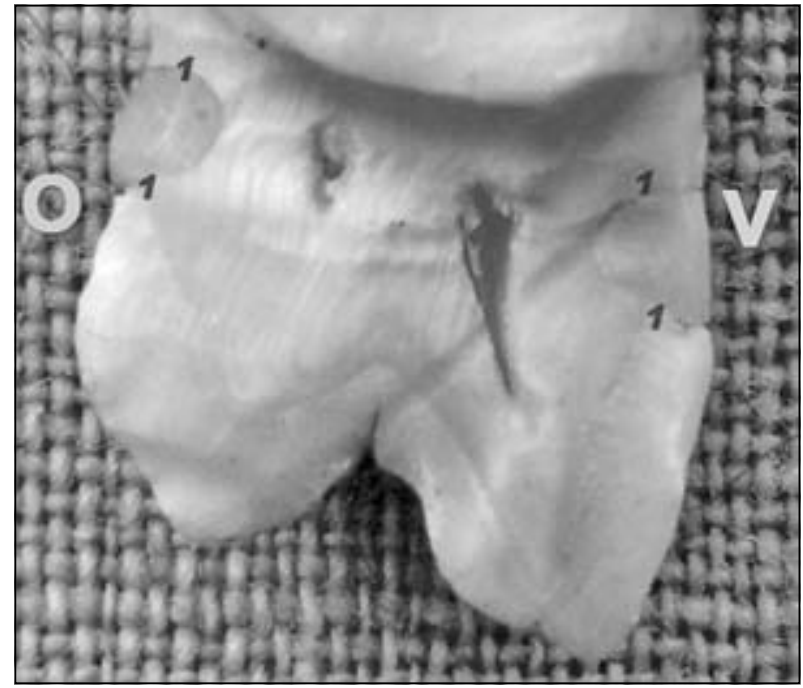

Figure 2. Microleakage indexes in both materials at the both edges have value $1 / 1$

Slika 2. Indeksi mikrocurenja kod oba materijala na obe ivice imaju vrednost $1 / 1$

$\mathrm{V}$ - vestibular side (Fuji II); O - oral side (Fuji II LC improved)

$\mathrm{V}$ - vestibularna strana (Fuji II); O - oralna strana (Fuji II LC improved)

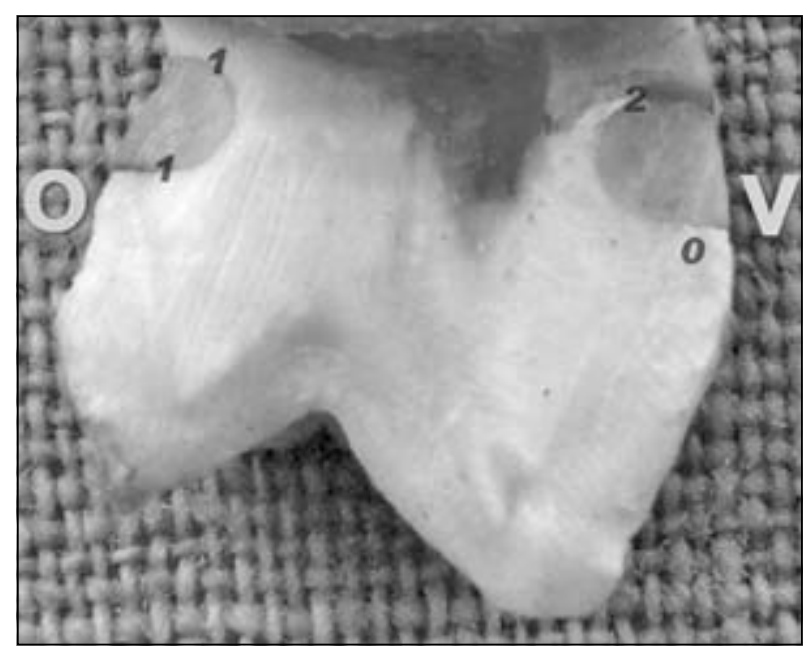

Figure 3. Microleakage indexes for $\mathrm{GlC}$ Fuji Il at the occlusal and gingival edges are $0 / 2$ and for GJC Fuji II LC are 1/1

Slika 3. Indeksi mikrocurenja kod GJC Fuji II na okluzivnoj i gingivalnoj ivici su 0/2, a za GJC Fuji II LC improved 1/1

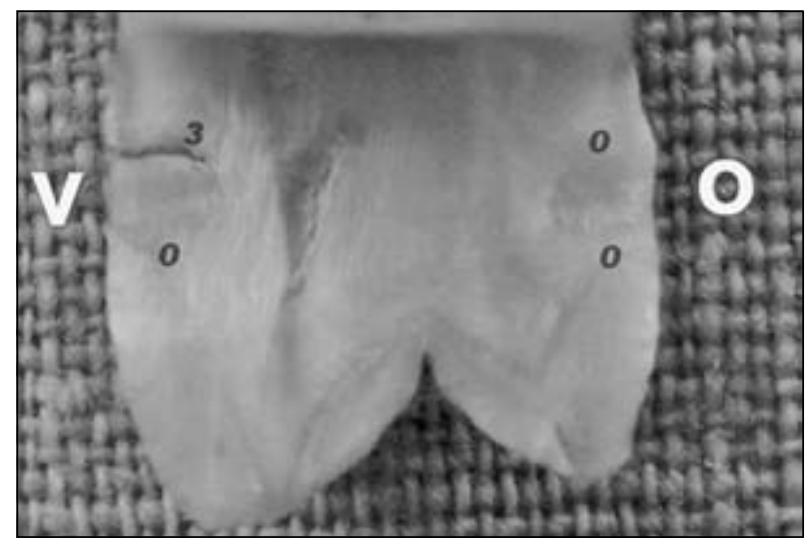

Figure 4. Microleakage index for GIC Fuji II at the occlusal and gingival edges is $0 / 0$ and for GJC Fuji II LC is $0 / 3$

Slika 4. Indeksi mikrocurenja kod GJC Fuji II na okluzivnoj i gingivalnoj ivici su 0/0, a za GJC Fuji II LC 0/3

\section{RESULTS}

Results of this investigation are shown in the Graphs 1 and 2 and Figures 2-7. A microgap existed between the tooth and GJC Fuji II in $93.44 \%$ teeth with the sum of microleakage index 148 on all edges. Microleakage in the teeth restored with GJC Fuji II LC was noticed in $68.4 \%$ cases and the sum of the index was 75 on all edges. Microleakage was higher at occlusal edges in the $30 \%$ teeth restored with Fuji II GJC, in $40 \%$ of the teeth at the gingival edges and for 30\% teeth the value of microleakage was the same oclusally and gingivally (Graph 1, Figure 2). For the teeth restored with Fuji II LC, the results were: in $15 \%$ of the teeth, a higher microleakage degree was registered at the occlusal part, in $35 \%$ of the teeth in the gingival edges and for $50 \%$ of the teeth the values were the same for occlusal and gingival edges (Graph 1, Figures 3 and 4). Comparing the microleakage on the 120 different surfaces of the teeth, in $50.83 \%$, Fuji II LC showed a lower degree while only in $15.83 \%$ of the surfaces microleakage was lower for Fuji II. In $33.33 \%$ of the surfaces, this parameter was the same (Graph 2).

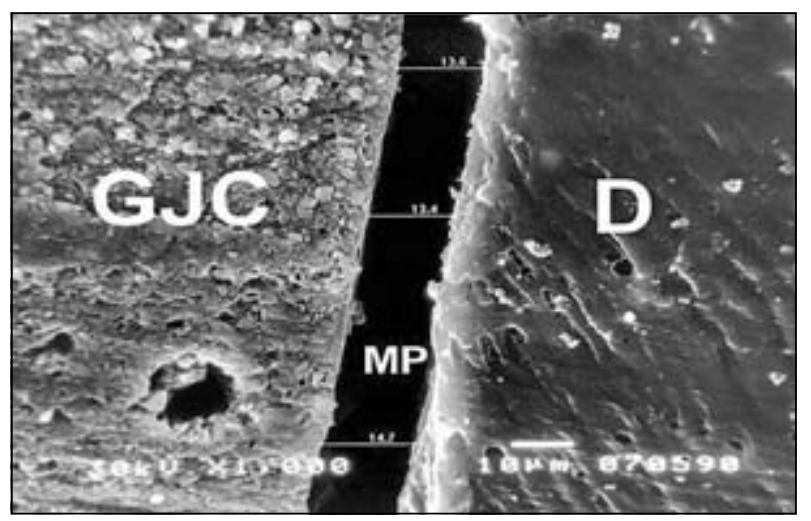

Figure 5. SEM of the microgap on the junction of Fuji II GIC and dentine at the bottom of the cavity (magnification 1000 times)

Slika 5. SEM fotografija mikropukotine na spoju Fuji II GJC i dentina na dnu kaviteta (uvećanje 1.000 puta)

GJC - glass ionomer cement; MP - microgap; D - dentine GJC - glasjonomer-cement; MP - mikropukotina; D - dentin

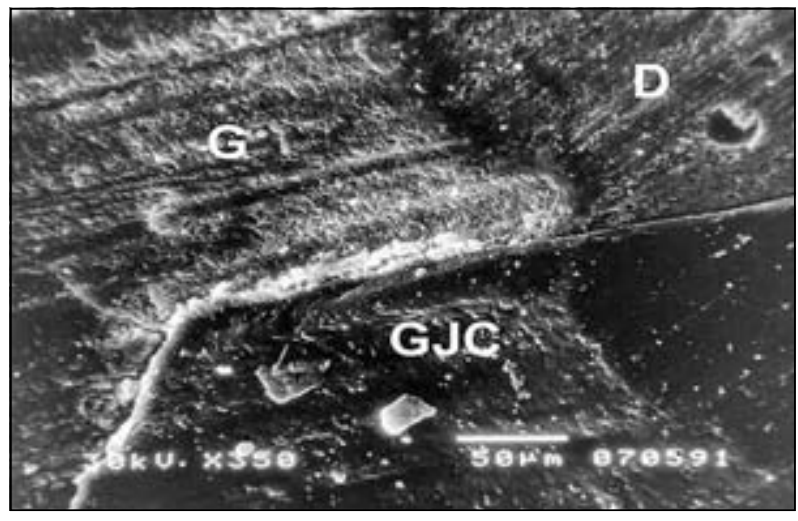

Figure 6. SEM photo on the junction of Fuji II GIC and hard dental tissue on the occlusal edge of the cavity (magnification 350 times) Slika 6. SEM fotografija spoja Fuji II GJC sa tvrdim zubnim tkivima na okluzivnoj ivici kaviteta (uvećanje 350 puta)

GJC - glass ionomer cement; D - dentine; $\mathrm{C}$ - enamel

GJC - glasjonomer-cement; D - dentin; G - gleđ 


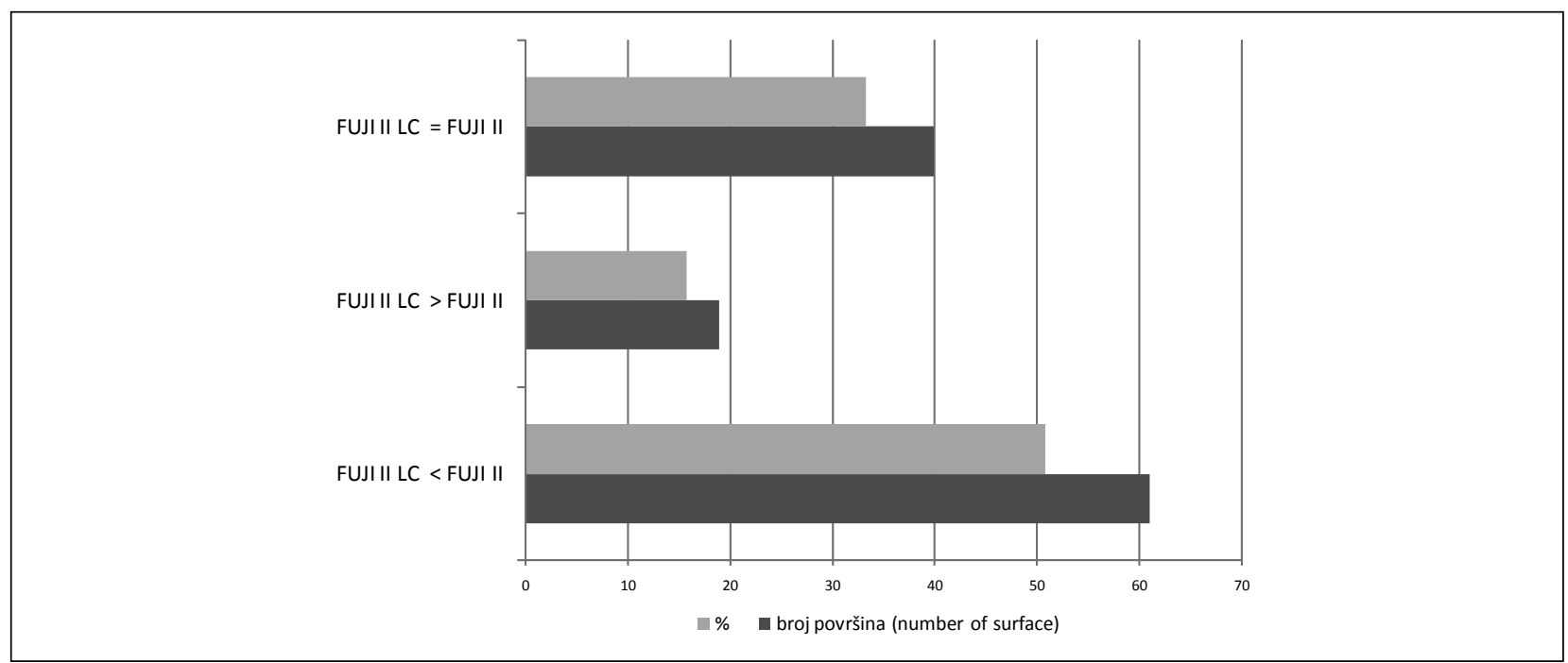

Graph 2. Comparison of the microleakage for Fuji II I Fuji II LC on all surfaces

Grafikon 2. Direktno poređenje Fuji II I Fuji II LC na svim površinama

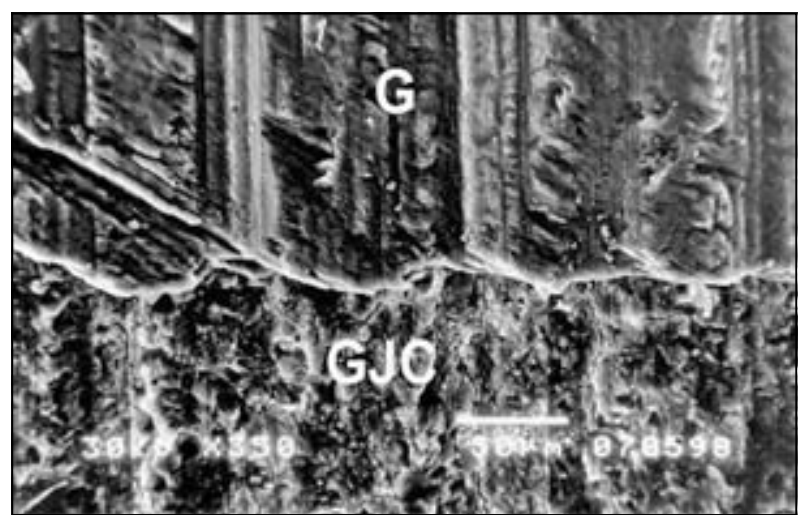

Figure 7. SEM photo on the junction of Fuji II GIC and enamel (magnification 350 times)

Slika 7. SEM fotografija spoja Fuji II LC i gleđi (uvećanje 350 puta)

GJC - glass ionomer cement; $G$ - ename

G) C - glasjonomer-cement; $\mathrm{G}$ - gleđ

Photos of the tested samples were analysed using the specific software-SemAfore 4 . The size of the microgap was also evaluated. Figures 5, 6 and 7 show different types of connections, present microgaps or good adhesion between material and hard dental tissue. The SEM analysis showed the mean value of the microgap for Fuji II LC of $9 \mu \mathrm{m}$, while this value was $17 \mu \mathrm{m}$ for Fuji II.

Figure 5 shows the bottom of the cavity for Fuji II at magnification of 1000 . The microgap (MG) is presented between dentine (D) and the filling (GJC). The size of the gap is $13-14.7 \mu \mathrm{m}$. High-quality connection is presented between Fuji II (GJC) and enamel (E) and dentine (D) at the magnification of 350 (Figure 6). Good adhesion between Fuji II LC (GJC) and enamel (E) was noticed at the magnification of 350 (Figure 7).

\section{DISCUSSION}

Since their introduction in dental practice, due to their good characteristics, GICs have been widely used in all branches of modern dentistry. Two different types of GICs were used in this study: conventional GC Fuji II and resinmodified Fuji II LC improved. GC Fuji II is a representative of the conventional GIC group that is most commonly used. Conditioning of hard dental tissues with a mild solution of polyacrilic acid in order to remove smear layer and preactivation of $\mathrm{Ca}^{2+}$ ions is necessary for this material. The material is very sensitive to moisture after application, therefore it is necessary to isolate it with protective liners. GC Fuji II LC is a representative of resin- modified glass-ionomer cements. These materials were created by adding resin material to ingredients of conventional GICs. This was done in order to solve one of the greatest deficiencies of conventional GICs, their sensitivity to moisture.

Differences in the size of micro-gap with these two materials can be explained by their different reaction to disbalance of water. Between $11 \%$ and $24 \%$ of hardened cement is water, therefore it can be said that GIC is waterbased cement. Percentage of water can be roughly divided into "weakly cohesive" that can be easily removed by dehydration and "strongly cohesive" water that cannot be removed and remains an important part of the hardening reaction as well as finally hardened cement. The advantage of resin modified GIC as well as Fuji II LC improved is particularly in this phase. Ca poliacryil chains are formed first, and then Al poliacryil chains with classic glass-ionomer. The same acid-base reaction happens with resinmodified glass-ionomer, like Fuji II LC, but instant resin polymerization protects the reaction from the moisture.

The value of the thermal expansion coefficient for conventional GICs is close to the thermal expansion coefficient of hard dental tissues, which has been recognized as an important reason of good marginal adaptation [10, 11]. Although resin modified GICs show stronger power of adhesion against hard dental tissues than conventional, they show different results regarding micro leakage as well $[12,13]$. Most of them show lower microleakage than the conventional GICs $[12,13,14]$. As reasons for better marginal adaptation are mentioned much smaller solubility in water $(0.07 \%$ for classic, and $0.03 \%$ for resin-modi- 
fied), different behaviour in acid environment (the classic are characterized by solubility in acids from $0.33 \%$, while mild swelling occurs with the resin modified ones), as well as the fact that the resin modified GICs are not sensitive to disbalance of water.

Clinical research made by Hallet and Garcia-Godoy [12] confirmed the results acquired in this research. They confirmed the fact that resin modified GICs had significantly lower micro leakage than conventional. Similar research has been conducted by Gladys et al. [13] who included a greater number of materials (two composts, one compomer, two conventional GICs and three resin modified GICs) and then compared marginal adaptation. The evaluation was performed using the dye penetration test. Micro leakage was detected with all materials, but it was the smallest with the resin modified GJCs.

The results of this experiment, where the average value of micro gap established by the SEM analysis for Fuji II LC was $9 \mu \mathrm{m}$ and $17 \mu \mathrm{m}$ for Fuji II, are in accordance with the results of the research conducted by Sidhu and Watson [14] and Lucia et al. [15]. They analysed two light cured GICs: Fuji II LC and VariGlas VLC for dentin adhesion. Teeth in the control group were restored by chemically polymerized GICs, Fuji Cap II, while teeth from the remaining two groups were restored by light-curing materials. The evaluation of the results was conducted by the SEM analysis. The average value of the gap registered with the control group was $26 \mu \mathrm{m}$, while in the experimental group was $8 \mu \mathrm{m}$ (Fuji II LC) and $10 \mu \mathrm{m}$ (VariGlas). Lightcured materials showed significant better adhesion than the control material.

Clinical findings from literature mainly agree with the fact that micro gap was present with all materials in a certain degree, but it was the smallest with the resin modified GICs [16-23]. The most important reason for that was the fact that the resin-modified GICs, compared to other restorative materials, have the thermal expansion coefficient similar to hard dental tissues (their dimensional changes are the smallest in comparison to other restorative materials) and they develop the strongest chemical bond with hard dental tissues [19-24].

According to the conducted researches and obtained results, it can be concluded that the degree of microleakage with GC Fuji II LC is smaller than GC Fuji II. This material can be considered as an efficient and acceptable material for restorative procedures and clinical use in proper indications.

\section{REFERENCES}

1. Živković S. Dentin adhezivna sredstva u stomatologiji. Beograd: Data status; 2007.

2. Mount GJ, Hume WR. Preservation and restoration of tooth structure. Brisbane, Australia; 1998.

3. Wilson AD. A hard decades work: Steps in the invention of the glass-ionomer cement. J Dent Res. 1996; 75:1723-7.

4. Wilson AD, McLean JW. Glass ionomer cement. Chicago: Quintessence; 1988.
5. Mallakh BF, Sarkar NK. Fluoride release from glass-ionomer cements in de-ionized water and artificial saliva. Dent Mater. 1990; 6:118-22.

6. Carvalho AS, Cury JA. Fluoride release from dental materials in different solutions. Oper Dent. 1999; 24:14-9.

7. Deschepper EJ, Berry EA, Cailleteau JG, Tate WH. A comparative study of fluoride release from glass-ionomer cements. Quintessence Int. 1991; 22:215-20.

8. Forsten L. Short and long-term fluoride release from glass-ionomer and other fluoride-containing filling materials in vitro. Scand J Dent Res. 1990; 98:179-85.

9. Gupta S, Khinda VI, Grewal N. A comparative study of microleakage below cemento-enamel junction using light cure and chemically cured glass ionomer cement liners. I Indian Soc Pedod Prev Dent. 2002; 20:158-64.

10. Burgess J, Norling B, Summitt J. Resin ionomer restorative materials: the new generation. J Esthet Dent. 1994; 6:207-15.

11. Morabito A, Defabianis P. The marginal seal of various restorative materials in primary molars. J Clin Pediatr Dent. 1997; 22:51-4.

12. Hallet KB, Garcia-Godoy F. Microleakage of resin-modified glassionomer cement restorations: an in vitro study. Dent Mater. 1993; 9:306-11.

13. Gladys S, Van Meerbeek B, Lambrechts P, Vanherle G. Microleakage of adhesive restorative materials. Am J Dent. 2001; 14:170-6.

14. Sidhu SK, Watson TF. Resin-modified glass-ionomer materials, Part I: Properties. Dental Update. 1995; 429.

15. Birkenfeld LH, Schulman A. Enhanced retention of glass-ionomer sealant by enamel etching: a microleakage and scanning electron microscopic study. Quintessence Int. 1999; 30:712-8.

16. Puckett AD, Fitchie JG, Karns L, Dellinger TM, Inman CC. Microleakage of a compomer compared to conventional and hybrid ionomers. Quintessence Int. 2001; 32:49-54.

17. Živković S, Petrović Lj, Todorović A. In vitro ispitivanja ivične mikropropustljivosti materijala u kavitetima II klase. Stom Glas S. 2001; 48:51-6.

18. Živković S, Kolar M, Blažić L, Vučetić M, Tošić G. Razmazni sloj na dentinu u restaurativnoj stomatologiji. Stom Glas S. 2004; 51:169-76.

19. Bashar AK, Alam MS, Hussain MA, Islam MM, Hossain MM. An in vitro microleakage study of different filling materials using dye penetration method. Bangladesh Med Res Counc Bull. 2006; 32(1):1-9.

20. Lott JR, Fitchie JG, Creasy MO, Puckett AD Jr. Microleakage of three conventional glass ionomers using 45Ca and methylene blue. Gen Dent. 2007; 55(1):15-8.

21. Wadenya R, Mante FK. An in vitro comparison of marginal microleakage of alternative restorative treatment and conventional glass ionomer restorations in extracted permanent molars. Pediatr Dent. 2007; 29(4):303-7.

22. Gerdolle DA, Mortier E, Droz D. Microleakage and polymerization shrinkage of various polymer restorative materials. I Dent Child (Chic). 2008; 75(2):125-33.

23. Browning WD. The benefits of glass ionomer self-adhesive materials in restorative dentistry. Compend Contin Educ Dent. 2006; 27(5):308-14; quiz 315-6.

24. Mali P, Deshpande S, Singh A. Microleakage of restorative materials: an in vitro study. I Indian Soc Pedod Prev Dent. 2006; 24(1):15-8.

\author{
Address for correspondence \\ Lado Davidović \\ Department for Restorative Dentistry and \\ Endodontics \\ School of Medicine Foča \\ University in East Sarajevo \\ Studentska bb, 73300 Foča \\ Bosnia and Herzegovina \\ Tel.: +387 (0)65029693 \\ Email: ladohak@yahoo.com
}




\title{
Ispitivanje mikrocurenja kod restauracija zuba glasjonomer-cementom
}

\author{
Lado Davidović1, Slavoljub Tomić1, Mihael Stanojević1, Slavoljub Živković2 \\ ${ }^{1}$ Katedra za bolesti zuba, Medicinski fakultet Foča, Univerzitet u Istočnom Sarajevu, Foča, Bosna i Hercegovina; \\ 2Klinika za bolesti zuba, Stomatološki fakultet, Univerzitet u Beogradu, Beograd, Srbija
}

\begin{abstract}
KRATAK SADRŽAJ
Uvod Nedostatak odgovarajuće adhezivnosti je jedan od najčešćih problema u savremenoj restaurativnoj stomatologiji i glavni uzrok nastanka mikropukotine na spoju materijala i tvrdih zubnih tkiva. Cilj ovog rada je bio da se SEM analizom i semikvantitativnim ispitivanjima, odnosno metodom bojenih rastvora proveri kvalitet veze dve vrste glasjonomer-cementnih (GJC) restauracija za tvrda zubna tkiva kod kaviteta $V$ klase.

Materijal i metode rada Klinička ispitivanja su obuhvatila 80 sveže ekstrahovanih intaktnih zuba (premolari i molari), izvađenih iz ortodontskih razloga kod pacijenata oba pola i različite starosti. Na svim zubima su sa vestibularne i oralne strane urađene jednopovršinske preparacije $V$ klase adhezivnog tipa sa zaobljenim zidovima kaviteta (dimenzija $3 \times 2 \times 2 \mathrm{~mm}$ ). Sa vestibularne strane primenjen je GJC Fuji II, a s oralne GJC Fuji II LC improved. Kvalitet veze je procenjivan semikvantitativnim ispitivanjima rubnog zaptivanja metodom bojenih rastvora i SEM analizom kvaliteta veze ispuna i zubnih tkiva. Kao bojeni rastvor korišćen je 0,5-procentni rastvor bazičnog fuksina, a linearni prodor boje na gingivalnom i okluzivnom delu kaviteta posmatran je pod lupom i pri uvećanju od deset puta.

Rezultati Dobijeni nalazi su pokazali da je kod oba materijala zabeležena mikropukotina i da je stepen mikrocurenja kod Fuji II LC bio manji nego kod Fuji II. Kod oba materijala je utvrđen manji stepen mikrocurenja na okluzivnim ivicama ispuna nego na gingivalnim. Mikrocurenje je ustanovljeno u 93,44\% zuba restauriranih sa Fuji II GJC, s ukupnim indeksom mikrocurenja 148 na svim ivicama. Kod Fuji II LC GJC mikrocurenje je zabeleženo u 68,4\% zuba, s ukupnim indeksom mikrocurenja 75 na svim ivicama. SEM analizom je utvrđeno da je veza oba ispitivana GJC sa gleđi mnogo bolja nego sa dentinom, a srednja vrednost mikropukotine otkrivene za Fuji II LC bila je $9 \mu \mathrm{m}$, dok je ova vrednost za Fuji II bila $17 \mu \mathrm{m}$.

Zaključak Na osnovu rezultata istraživanja može se zaključiti da je bolji kvalitet veze ostvaren primenom materijala novije generacije, odnosno primenom GJC modifikovanih smolom.
\end{abstract}

Ključne reči: mikrocurenje; adhezivnost; glasjonomer-cement

\section{UVOD}

Na početku trećeg milenijuma može se reći da još ne postoji materijal koji potpuno odgovara fizičkim, hemijskim i biološkim osobinama zubnih tkiva i koji bi bio adekvatna zamena za nadoknadu čvrste zubne supstance. Danas se u restaurativnoj stomatologiji najčešće koriste kompozitni materijali i glasjonomer-cementi (GJC), koji ispunjavaju najveći broj zahteva restaurativnog postupka. Međutim, najveći problem kompozitnih materijala u savremenoj restaurativnoj stomatologiji je pojava mikropukotine na spoju materijala i tvrdih zubnih tkiva. Na njen nastanak utiču mnogi faktori, među kojima su: dizajn preparacije kaviteta, način i tehnika restauracije, dimenzionalne promene u materijalu za vreme stvrdnjavanja, razlike u koeficijentu termičke ekspanzije zuba i restaurativnog materijala, odnosno različita termička provodljivost zuba i ispuna. Klinički se ispoljava ivičnim prebojavanjem, oštećenjem rubova ispuna i nastankom znakova iritacije ili zapaljenjem pulpe zuba uz razvoj sekundarnog karijesa [1, 2].

Kao materijal u restaurativnoj stomatologiji u brojnim indikacijama se koriste i GJC, koji sa tvrdim zubnim tkivima ostvaruju hemijski tip veze. Od pojave prvih GJC (konvencionalnih) sedamdesetih godina dvadesetog veka do danas, ovi materijali su pretrpeli razne promene. Jedna od suštinskih promena ogleda se u dodatku kompozitnih smola konvencionalnim GJC i nastanku tzv. GJC modifikovanih smolom. Osnovni cilj smole je poboljšanje mehaničkih i estetskih osobina GJC, kao i zaštita vrlo važne acidobazne reakcije tokom koje dolazi do stvrdnjavanja materijala $[3,4]$. Osobine koje ove materijale čine jedinstvenim su gotovo istovetan koeficijent termičke ekspanzije kao i kod tvrdih zubnih tkiva, značajna adhezivnost, biokompatibilnost i oslobađanje fluorida [5-8]. Upravo zahvaljujući tim osobinama GJC predstavljaju materijal koji je u ekspanziji i u sve većoj meri se primenjuje u brojnim indikacijama u svakodnevnoj kliničkoj praksi [9].

Cilj ovog rada je bio da se SEM analizom i semikvantitativnim ispitivanjima, odnosno metodom bojenih rastvora proveri kvalitet veze dve vrste glasjonomer-cementnih restauracija za tvrda zubna tkiva kod kaviteta V klase.

\section{MATERIJAL I METODE RADA}

Kao materijal u istraživanjima korišćeno je 80 ljudskih sveže ekstrahovanih intaktnih zuba (premolari i molari), izvađenih iz ortodontskih razloga, koji su do eksperimenta čuvani u fiziološkom rastvoru. Kod 60 zuba rubno zatvaranje je proveravano metodom bojenih rastvora, a kod 20 zuba je kvalitet adhezivne veze proveravan SEM ispitivanjima.

\section{Kvalitativno ispitivanje rubnog zaptivanja metodom bojenih rastvora}

Na svim zubima sa vestibularne i oralne strane urađene su jednopovršinske preparacije adhezivnog tipa klase V sa zaobljenim zidovima kaviteta (dimenzija $3 \times 2 \times 2 \mathrm{~mm}$ ). Rubovi kaviteta su bili potpuno u gleđi, a gleđne prizme nisu zakošavane. Za preparaciju u gleđi korišćena je visokoturažna bušilica sa dijamantskim svrdlima i vodenim hlađenjem. Za preparaciju 
u dentinu je korišćen kolenjak sa čeličnim okruglim svrdlima. Nakon preparacije kaviteta urađeno je kondicioniranje površina (Cavity Conditioner), a potom su kaviteti isprani vodom i posušeni sterilnim kuglicama vate. U tako pripremljene kavitete postavljen je materijal u skladu s uputstvima proizvođača.

Sa vestibularne strane primenjen je klasičan GJC Fuji II, a s oralne strane GJC modifikovan smolom Fuji II LC improved. Posle unošenja materijala preko ispuna je stavljena celuloidna matrica, a kod GJC Fuji II LC improved izvršena je i polimerizacija materijala halogenom lampom (Bluephase C8, Ivoclar Vivadent). Neposredno nakon uklanjanja matrice ispuni su premazani sa GJC Fuji Varnish i posušeni mlazom vazduha, a potom ispolirani. Zubi su zatim premazani sa dva sloja laka (osim ispuna i $1 \mathrm{~mm}$ oko ispuna) i potopljeni u rastvor od 0,5\% bazičnog fuksina u trajanju od 72 časa. Nakon toga zubi su isečeni u vestibulo-oralnom pravcu, po sagitalnoj ravni. Prodor boje je posmatran pod lupom pri desetostrukom uvećanju, kako na okluzivnim, tako i na gingivalnim rubovima. Dubina prodora boje je vrednovana po kriterijumima koji su šematski prikazni na slikama la i $1 \mathrm{~b}$ [9].

\section{SEM istraživanje kvaliteta veze ispuna i zubnih tkiva}

Nakon cepanja zuba u vestibulo-oralnom pravcu, preseci su fiksirani na metalne valjke, a zatim u vakuum-aparatu naparavani tankim slojem plemenitih metala. Ovako dobijeni preparati posmatrani su skening elektronskim mikroskopom (JEOL, JSM5300) pri maksimalnom naponu od $30 \mathrm{kV}$, na različitim uvećanjima. Preparati su fotografisani aparatom JVC GC-X3E na filmovima ILFORD FP4 PLUS 125 (125 ASA, 22 DIN, EI 125/22).

$\mathrm{Na}$ snimcima su analizirani izgled veze i eventualna pojava mikroprostora između zubnih tkiva i ispuna sa GJC. Za analizu fotografija, određivanje veličine mikropukotine i prikaz dobijenih vrednosti na fotografijama preparata korišćen je softver SemAfore4. Nakon prikupljanja i obrade podataka za utvrđivanje statističke značajnosti korišeni su test ekvivalentnih parova, test sume rangova, jednofaktorska analiza varijanse za proporciju i analiza varijanse pomoću rangova.

\section{REZULTATI}

Rezultati istraživanja prikazani su na grafikonima 1 i 2 i na slikama 2-7. Kod zuba restauriranih sa GJC Fuji II mikropukotina je zabeležena kod 93,44\% zuba, s ukupnim indeksom mikrocurenja 148 na svim ivicama. Kod zuba restauriranih sa GJC Fuji II LC mikrocurenje je uočeno kod 68,4\% zuba, s ukupnim indeksom mikrocurenja 75 na svim ivicama. Rezultati stepena mikrocurenja su pokazali da je kod Fuji II GJC u 30\% zuba stepen mikrocurenja bio veći na okluzivnim ivicama, u $40 \%$ zuba veći na gingivalnim ivicama, dok su u $30 \%$ zuba vrednosti bile jednake (Grafikon 1, Slika 2). Kod Fuji II LC u 15\% zuba je zabeležen veći stepen mikrocurenja na okluzivnim ivicama, u $35 \%$ zuba veći na gingivalnim ivicama, a u $50 \%$ zuba vrednosti su bile jednake (Grafikon 1, Slike 3 i 4). Dobijeni rezultati su takođe pokazali da je od 120 međusobno upoređenih površina u $50,83 \%$ slučajeva Fuji II LC pokazao manji stepen mikrocurenja, da je kod Fuji II u 15,83\% slučajeva uočen manji stepen mikrocurenja, dok je u 33,33\% ovaj parametar bio isti (Grafikon 2).
Mikrofotografije ispitanih uzoraka analizirane su na računaru pomoću softvera za obradu i analizu SEM fotografija (SemAfore 4). Istim softverom je određena i veličina mikropukotine u svim pojedinačnim slučajevima. Na mikrofotografijama (Slike 5, 6 i 7) uočeni su različiti tipovi veze, počev od jako izraženih mikropukotina do slučajeva sa dobrom adhezijom i intimnim kontaktom materijala za zubna tkiva. SEM analizom je zabeležena srednja vrednost mikropukotine za Fuji II LC od 9 $\mu \mathrm{m}$, dok je ova vrednost za Fuji II bila $17 \mu \mathrm{m}$.

Na slici 5 se uočava dno kaviteta ispuna Fuji II pri uvećanju od 1000 puta. Uočava se mikropukotina (MP) između dentina (D) i ispuna (GJC). Veličina mikropukotine bila je 13-14,7 $\mu \mathrm{m}$. Na slici 6 intiman i kontinuiran spoj materijala i zubnih tkiva uočava se na preparatu koji prikazuje odnos Fuji II GJC i gleđi (G) i dentina (D) pri uvećanju od 350 puta. Na slici 7 vidi se dobra adhezivna veza između Fuji II LC (GJC) i gleđi (G), koja je prikazana pri uvećanju od 350 puta.

\section{DISKUSIJA}

Od uvođenja u svakodnevnu stomatološku praksu, GJC su zahvaljujući svojim dobrim osobinama našli široku primenu u gotovo svim granama savremene stomatologije. U ovom istraživanju upotrebljene su dve vrste GJC: konvencionalni GJC (Fuji II) i GJC modifikovan smolom (Fuji II LC improved). GJC Fuji II je predstavnik grupe konvencionalnih GJC koja se danas najčešće koristi. Kod ovog materijala primenjuje se kondicioniranje tvrdih zubnih tkiva blagim rastvorom poliakrilne kiseline radi uklanjanja razmaznog sloja i preaktivacije jona kalciju$\mathrm{ma}\left(\mathrm{Ca}^{2+}\right)$. Nakon postavljanja ispuna materijal je izrazito osetljiv na vlagu, te je neophodna izolacija zaštitnim premazima. GJC Fuji II LC je predstavnik GJC modifikovanih smolom. Ovi materijali su dobijeni dodavanjem kompozitne smole u sastav konvencionalnih GJC. Ovo je urađeno da bi se rešio jedan od najvećih nedostataka konvencionalnih GJC materijala - njihova osetljivost na disbalans vode.

Razlike u veličini mikropukotine kod dva ispitivana materijala mogu se objasniti različitom reakcijom samih materijala na disbalans vode. Između $11 \%$ i $24 \%$ stvrdnutog cementa je voda, tako da se za glasjonomere može reći da su na bazi vode. Udeo vode se deli na „slabo vezanu” vodu, koja se lako odstranjuje dehidratacijom, i „čvrsto vezanu” vodu, koja se ne može odstraniti i ostaje važan deo reakcije stvrdnjavanja, kao i završno stvrdnutog cementa. Upravo u ovoj fazi GJC modifikovan smolom (Fuji II LC improved) ima značajnu prednost. Kod klasičnog GJC, kao što je Fuji II, prvo se formiraju kalcijumski poliakrilatni lanci, a zatim i aluminijumski poliakrilatni lanci. Kada je reč o GJC koji su modifikovani smolom, kao što je Fuji II LC, javlja se potpuno ista acidobazna reakcija, ali je ona zaštićena od disbalansa vode trenutnom polimerizacijom smole.

Koeficijent termičke ekspanzije konvencionalnih GJC ima vrednosti slične vrednostima tvrdih zubnih tkiva i navodi se kao značajan razlog dobrog rubnog zatvaranja GJC restauracija $[10,11]$. Iako GJC modifikovani smolom ispoljavaju jaču snagu adhezije za tvrda tubna tkiva od konvencionalnih, oni pokazuju i različite rezultate u pojavi mikrocurenja $[12,13]$. Većina njih pokazuje manji stepen mikrocurenja od konvencionalnih GJC $[12,13,14]$. Kao razlozi boljeg rubnog zatvaranja GJC modifikovanih smolom navode se: mnogo manja rastvorljivost u vodi 
(kod klasičnih GJC ona je $0,07 \%$, a kod modifikovanih smolom $0,03 \%$ ), različito ponašanje u kiseloj sredini (klasične odlikuje rastvorljivost $\mathrm{u}$ kiselinama od $0,33 \%$, dok se kod modifikovanih smolom javlja blago bubrenje), te činjenica da GJC modifikovani smolom nisu osetljivi na disbalans vode.

Klinička ispitivanja Haleta (Hallet) i Garsija-Godoja (GarciaGodoy) [12] su potvrdila rezultate našeg istraživanja. Ovi autori su takođe potvrdili da GJC modifikovan smolom ima značajno manji stepen mikrocurenja od konvencionalnog. Slična istraživanja su izveli i Gledis (Gladys) i saradnici [13], koji su uključili veći broj materijala (dva kompozitna, jedan kompomer, dva konvencionalna GJC i tri GJC modifikovana smolom) i potom upoređivali rubno zatvaranje. Procena je vršena metodom bojenih rastvora. Kod svih materijala je zabeležena pojava mikropukotine, ali je najmanja bila kod GJC modifikovanih smolom.

Rezultati našeg istraživanja u kojem je SEM analizom srednja vrednost mikropukotine za Fuji II LC bila $9 \mu$ m, a za Fuji II $17 \mu \mathrm{m}$, u skladu su s nalazima do kojih su došli Sidu (Sidhu) i Votson (Watson) [14] i Lucija (Lucia) i saradnici [15]. Oni su ispitivali adheziju za dentin dva svetlosnopolimerizujuća GJC: Fuji II LC i VariGlas VLC. Zubi kontrolne grupe su restaurirani hemijskopolimerizujućim GJC (Fuji Cap II), dok su zubi iz preostale dve grupe restaurirani svetlosnopolimerizujućim materijalima. Ocena rezultata je izvršena SEM analizom. Srednja vrednost zjapa zabeležena kod zuba kontrolne grupe bila je $26 \mu \mathrm{m}$, a zuba eksperimentalne grupe $8 \mu \mathrm{m}$ (Fuji II LC) i $10 \mu \mathrm{m}$ (VariGlas VLC). Svetlosnopolimerizujući materijali su pokazali znatno bolju adheziju od kontrolnog materijala.

Klinički nalazi iz literature se uglavnom slažu u činjenici da je kod svih restaurativnih materijala mikropukotina prisutna u određenoj meri, ali da je ona najmanja kod GJC modifikovanih smolom [16-23]. Osnovni razlog je u tome što ovi GJC u odnosu na ostale restaurativne materijale imaju najusklađeniji koeficijent termičke ekspanzije sa tvrdim zubnim tkivima (njihove dimenzionalne promene su najmanje u odnosu na druge restaurativne materijale) i razvijaju najjaču hemijsku vezu sa tvrdim zubnim tkivima od svih [19-24].

$\mathrm{Na}$ osnovu dobijenih rezultata istraživanja može se zaključiti da je stepen mikrocurenja kod GJC Fuji II LC manje izražen nego kod GJC Fuji II. Ovaj materijal se može smatrati efikasnim i prihvatljivijim za restaurativni postupak i kliničku upotrebu u odgovarajućim indikacijama. 